\title{
GENERAL PRACTICE NURSING STUDENTS‘ STRESS DURING PROFESSIONAL INTERNSHIP: CAUSES AND STRESS COPING METHODS
}

\author{
Viktorija Piščalkienė, Lijana Navickienė \\ Kaunas University of Applied Sciences, Faculty of Medicine, Lithuania
}

Keywords: nursing students, stress, professional internship, stress causes, stress coping methods.

\section{Summary}

Occupational stress is a phenomenon faced by both physicians working in health care institutions and students studying in the medicine and nursing fields. Early identification of the stress factors and application of timely and targeted stress coping methods are measures allowing to maintain a safe socio-educational environment in a real practical place.

The aim of the study - to reveal the causes of nursing students' stress during their professional internship and to identify what strategies students use to cope with the stress.

Material and methods. For the study a quantitative research strategy was used. The survey instrument included questions of two main blocks, one of which was related to stressors, the other one covered stress coping methods. 27 items of stress causes were listed in the questionnaire covering 4 main areas: 1) work content and clinical situations; 2) work conditions and organization; 3) communication and collaboration; 4) external stressors.

For revealing what measures students use to manage their stress 26 items of stress coping methods were included into the questionnaire. These methods are related to 4 types of stress coping strategies: 1) Relaxation methods; 2) Rational methods; 3) Organizational and social; 4) Pharmaceutical and health damaging habits. Research instrument also included an open question which was aimed to find out positive students' experiences during the internships. 145 nursing students participated in the study. Results. Stress is a common phenomenon among nursing students. All nursing students experience higher or lower level of stress during the professional internships. Factors related to work conditions and organization are the most stressful. Rational stress management methods are the most popular among nursing students in dealing with stressful situations during professional internships. The positive experience expressed by nursing students during internships can be considered as measures helping to successfully adapt psychologically and reduce stress during internships. Basing on the study results such students support measures could be identified as: student praise and encouragement, friendly team and close cooperation, nurse-mentor as teacher and consultant, confidence in student and the opportunity to act independently, patient's gratitude and benevolence.

\section{Introduction}

Healthcare professionals belong to an increased risk group in terms of work stress and occupational burnout. Students studying nursing spend half of their study time in a real internship place. During the internships prospective nurses are likely to experience the same stressful situations as nurses- practitioners in their professional activity.

Research shows that nursing and health care students experience moderate to high stress during their internship. The most common causes of student stress are the performance of technical procedures, the use of new technologies and equipment, new and unexpected clinical situations, uncoordinated relationships with staff, lack of confidence in student capabilities, lack of psychological support, organizational aspects of work, patients who are in critical condition or aggressive $[11 ; 13]$. Nursing students can also be stressed by those who are to help students adapt psychologically to the new future professional environment. The results of various studies show that teachers and nursing staff cause strong stress because students feel they are constantly being observed and evaluated [4].

In the face of the global coronavirus pandemic (COVID-19), healthcare professionals and interns are among those who may be more responsive to the pandemic stress. It is confirmed by the performed studies that stress level of 


\section{4}

nursing students have increased during the pandemic [1;9].

Though stress is treated as a normal reaction to threatening circumstances, it may have detrimental effect to health. Stress may be a cause of insomnia, musculoskeletal pains (back, shoulder, arm, neck), skin problems and other [10; 12]. Stress may be harmful for students' personal and professional wellbeing, demotivating for the studies and profession, and may cause poor academic results and elevated burnout levels. Stressors may create difficulties in learning practical skills, allow for unexpected mistakes, lack of concentration etc.

The stress coping strategies might be helpful for students to effectively deal with various stressors, be liable to influence academical success, stress management skills allow optimum performance in the future $[2 ; 5 ; 8]$. Preparation of special programs, facilitating and engaging in solving students' difficulties, giving advice, and reflecting on their daily activities as well as the use of effective coping strategies may improve the quality of nursing studies and care for the patients $[3 ; 6 ; 7]$.

The study aims to reveal the causes of nursing students' stress during their professional internship and to identify what strategies students use to cope with the stress.

\section{Material and methods}

For the study a quantitative research strategy was used. The survey instrument included questions of two main blocks, one of which was related to stressors, the other one covered stress coping methods. 27 items of stress causes were listed in the questionnaire covering 4 main areas: 1) work content and clinical situations (requirements for nursing specialist's competencies, functions, tasks, responsibilities, fear of seriously ill or dying patients, fear of infectious diseases); 2) work conditions and organization (work environment, physical conditions; workload, time management, control); 3) communication and collaboration (encouragement, conflicts, support, autonomy); 4) external stressors (health policy, professional status in society, demographic situation).

For revealing what measures students use to manage their stress 26 items of stress coping methods were included into the questionnaire. These methods are related to 4 types of stress coping strategies: 1) Relaxation methods - soothing, relaxing techniques that help to regain well-being. These techniques include physical activities, massages, focus attention, body relaxation, breathing, imagination and emotional control exercises. 2) Rational methods - include deepening of self-perception and cognition ways to strengthen the ego, the establishment of clear and flexible limits for self-determination, learning to explore and manage thoughts, promote rational and positive thinking. 3) Organizational and social methods - include social support methods provided at organization for promoting proper organizational microclimate, relationships, open communication and support. 4) Pharmaceutical and health damaging habits - include use of stress-lowering drugs, alcohol, smoking.

Research instrument also included an open question which was aimed to find out positive students' experiences during the internships.

The research data was processed using the SPSS software (Statistical Package for Social Sciences, version 21.0). Methods used for statistical analysis include descriptive statistics, Cronbach's Alpha, T-test, Anova test. The data obtained from the open question was analysed using the content analysis method.

Cronbach's alpha of the scale was found to be 0,65 in a study of its reliability.

Targeted, convenient and relevant to the research context research sample was applied. The survey target group included nursing students of the 2nd, 3rd and 4th study year studying in general practice nursing study programme at

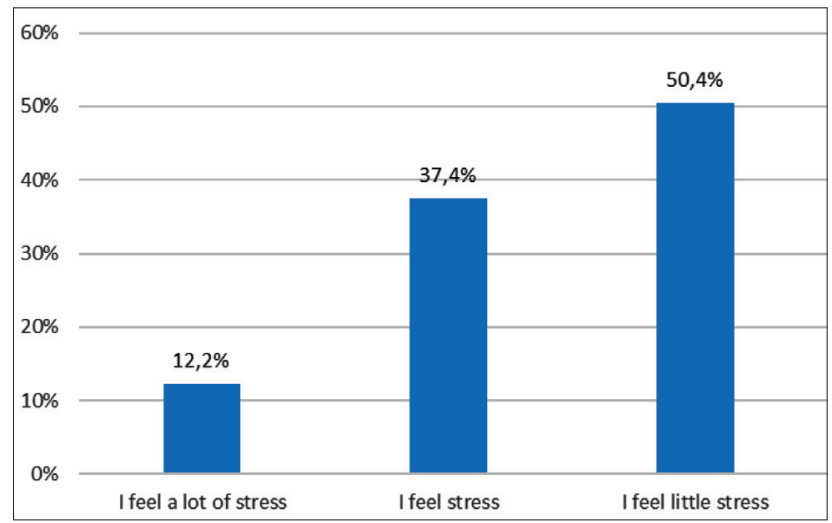

Fig. 1. Nursing students stress during professional internship (N $=145$ )

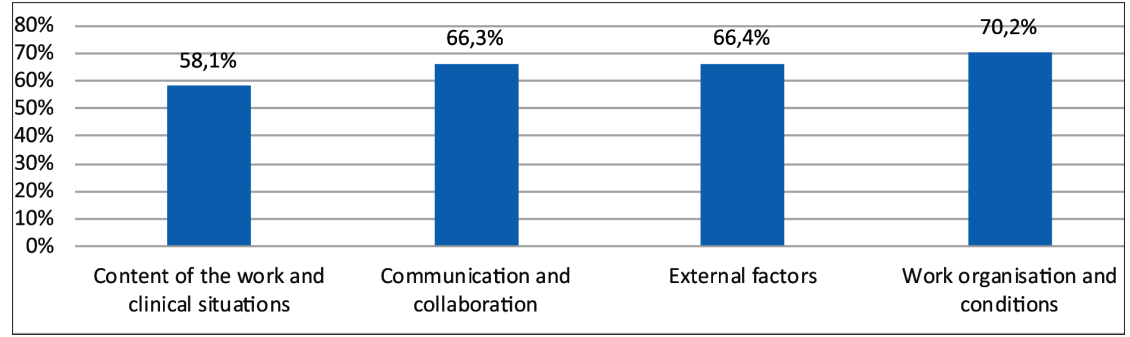

Fig. 2. Areas of stressors during professional internship $(\mathrm{N}=145)$ 
Kaunas University of Applied Sciences. First-year students were not surveyed because they had not yet had professional internships. At the time of the study 280 of the target group students studied in Nursing department at Kaunas University of Applied Sciences. 145 of them participated in the survey: $24.8 \%$ of the 2 nd year, $31 \%$ of the 3 rd year, 44.1 $\%$ of the 4 th year.

Students represented the following age groups: under 25 years $86.9 \%$, 26-35 years - $4.1 \%$ percent. 36 and more years - $9 \%$.

Participation in study was based on volunteering principle. The anonymity of study participants was ensured. The survey was carried out in December, 2019 - January, 2020.

\section{Results}

Stress causes during professional internship. Study data show that all nursing student feel stress during their professional internship (Fig.1). The level of stress felt by every second student varies from moderate to high.

Nursing students face stress in all 4 stressors areas (Fig. 2). Students are most stressed by factors related to the area "Work organization and conditions" (70\%). Different stressors under the areas "Communication and collaboration" and "External factors" are the cause of stress for slightly more than $2 / 3$ of students during their internships. Stressors belonging to the area "Content of the work and clinical situation" cause stress to $58.1 \%$ of general practice nursing students.

Stress factors under the area "Content of the work and clinical situation" are distributed differently (Fig. 3). Most nursing students experience stress linked to fear of infection from various infectious diseases $(80 \%)$. More than half of the nursing students are stressed by situations related to changing requirements for the role and competencies of a nurse (69\%), filling in documents, abundance of paperwork (60\%) and unclear duties and responsibilities (58,6\%). Only one in two nursing students is stressed by severely ill or dying patients $(51 \%)$. The least stressful factor for students during professional internships is professional development and licensing. This stressor was indicated by $1 / 3$ of the nursing students.

Factors related to work organization and conditions are the most stressful among nursing students. For majority students stress is caused by lack of staff $(90,3 \%)$ and heavy workload $(87.5 \%)$. Situations like urgent execution of unplanned additional tasks, large number of patients and lack of nursing remedies and technical equipment also cause considerable stress for

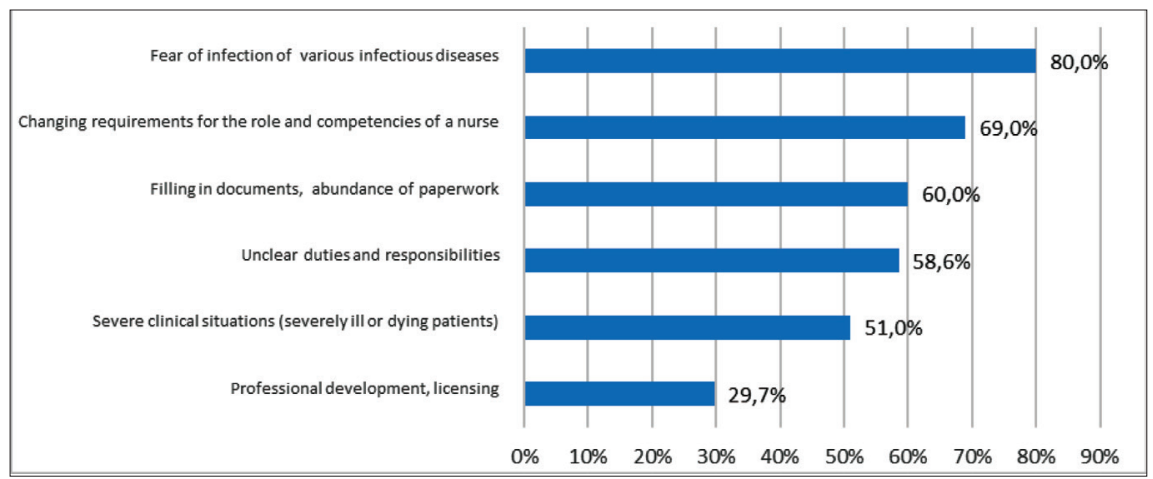

Fig. 3. Nursing students stress related to content of the work and clinical situation during professional internship $(\mathrm{N}=145)$

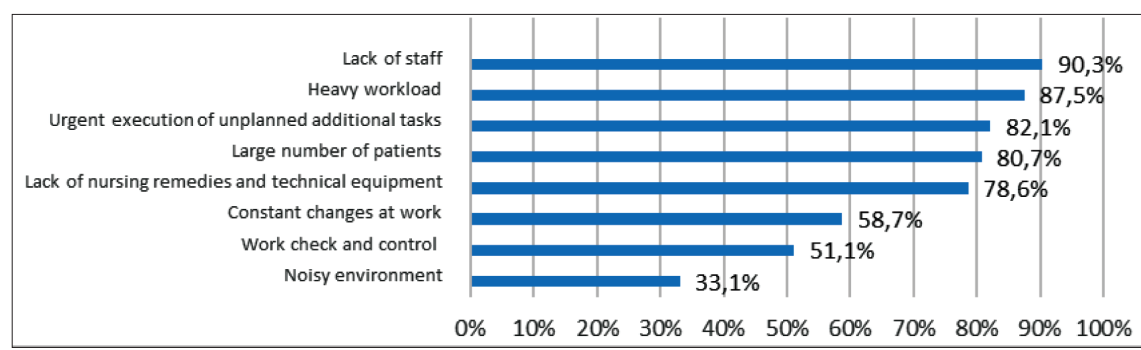

Fig. 4. Nursing students stress related to work organization and conditions during professional internship $(\mathrm{N}=145)$

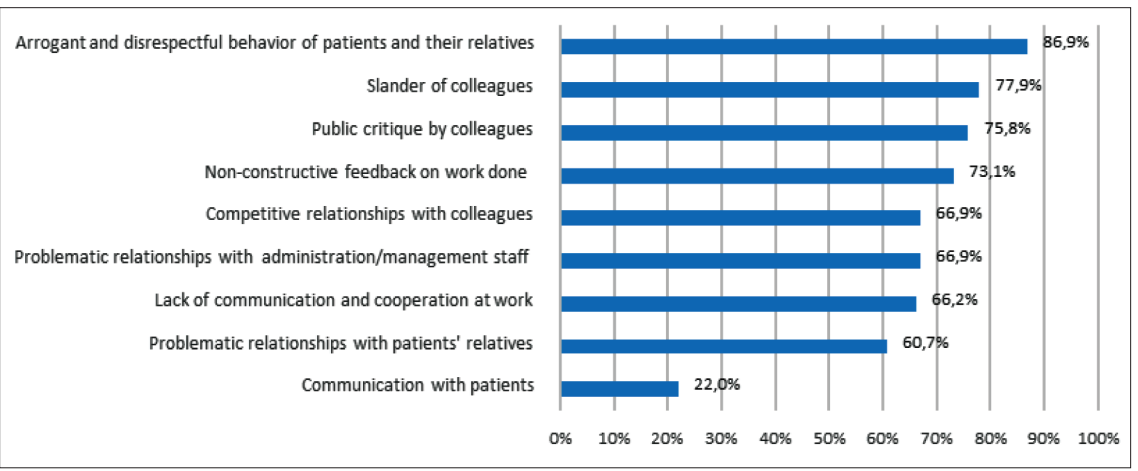

Fig. 5. Nursing students stress related to communication and collaboration during professional internship $(\mathrm{N}=145)$ 
nursing students. On average, every second student is stressed by work check and control. Noisy environment is stressful only for $1 / 3$ nursing students (Fig. 4).

Smooth communication and collaboration is a very important area during professional internships. However, this area is underdeveloped, there exist a lack of constructiveness, value-based collaboration between staff, patients, and nursing students (Fig. 5). $86.9 \%$ of nursing students are stressed by arrogant and disrespectful behaviour of patients and their relatives. According to nursing students, there exist problematic relationships with staff during internships. The majority of respondents indicated that they are stressed by slander of colleagues $(77.9 \%)$, public critique $(75.8 \%)$, nonconstructive feedback on work done (73.1\%). During internships nursing students are stressed not by communication as a phenomenon, but by problematic situations that arise in the communication process. At least $2 / 3$ of nursing students mentioned that they are stressed by problematic relationships with patients' relative, lack of communication and cooperation at work, problematic relationships with administration/management staff, competitive relationships with colleagues. Only $22 \%$ of nursing students point out that communication with patients is a cause of stress during internship.

External factors that are related to policy decisions in the health care system, the image of nurses in society, and the growth of an aging society are also related to the

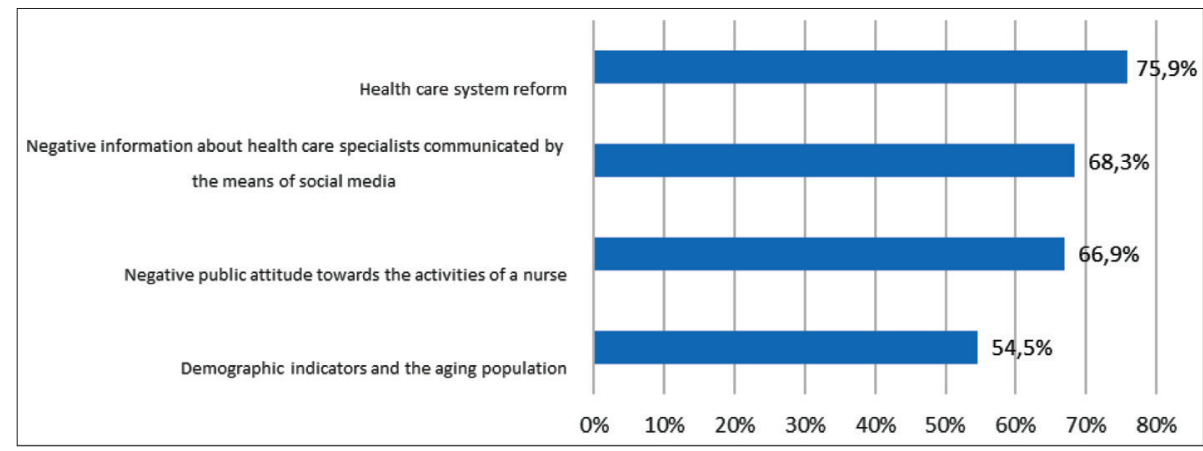

Fig. 6. Nursing students stress related to external factors during professional internship $(\mathrm{N}=145)$

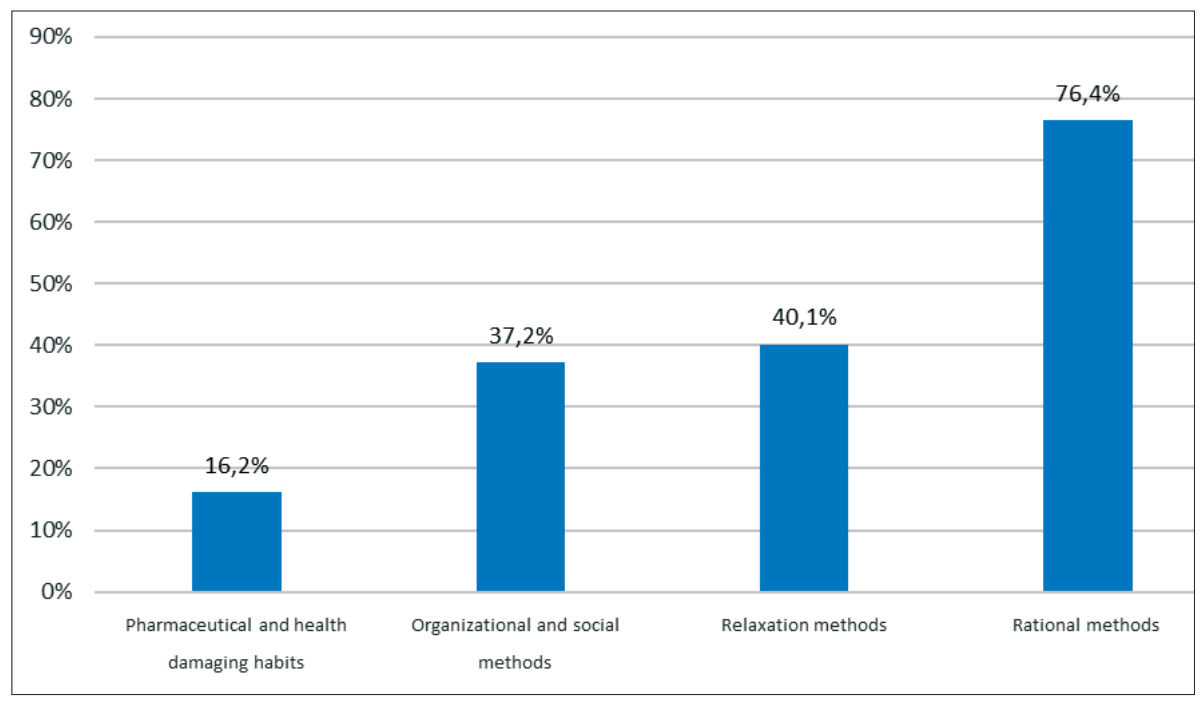

Fig. 7. Stress coping methods during professional internship $(\mathrm{N}=145)$ stress of nursing students during internships (Fig. 6) The external stress causing factors are rated by the study respondents as follows: health care system seems stressful for $75.9 \%$ students, negative information about health care specialists on social media causes stress for $68.3 \%$ students, and negative public attitude towards the activities of nurses causes stress for 66.9 $\%$ students. It might be assumed that students are fully prepared to work with older people, as one in two nursing students in the study indicated that demographic indicators and the aging population put them under stress.

No statistically significant differences were found indicating that the year of study is related to stress during internship (Anova test, $\mathrm{p} \geq 0.05$ ). Working students are less affected by stress during internship in these dimensions: ,communication and collaboration", ,,work content and clinical situations", „work conditions and organization" $(\mathrm{p} \leq 0,05)$.

\section{Stress coping methods}

The study showed that rational methods for managing stress during professional practices are the most popular - as many as $76.4 \%$ of respondents reported to use these methods (Fig. 7). Less applied stress management strategies are related to relaxation methods (40.1\%), organizational and social methods (37.2\%) and pharmaceutical and health damaging habits (16.2\%).

All rational stress management methods are reported to be widely applied by the nursing students in face of stress (Fig. 
$8)$. The methods focused on managing thoughts and promoting rational and positive thinking are used by more than $80 \%$ of the respondents (I calm myself down that I will overcome the difficulties, I think over what I've learnt from the situation, I recall my previous successful experiences of resolving the problem, I am convincing myself that I am a professional and have the necessary skills to solve the problem). A very similar proportion of students stated that they try to find out more or something positive about the situation, take some other work or activities to redirect thoughts from the issue. $2 / 3$ of nursing students facing stress during practice use the methods of making joke of the situation and thinking over the stressful situation and developing an action plan to cope with it. Setting aside the problem having intention to look at the situation later is the least used stress coping measure among the students. Only $42.8 \%$ of the respondents reported they applied this method.

Relaxation stress managing methods, unlike rational ones, are much less used among nursing students (Fig. 9). Commonly used relaxation techniques include calming down and relaxing in a creative way $(55.9 \%)$ and doing sports $(50.3 \%)$. This stress coping measures are reported to be applied by every second of the surveyed students.

Organizational and social stress coping methods also are not very popular among nursing students (Fig. 10). The study results suggest that nursing students have the most trust in nursing practitioners who are close to their place of practice. $75.2 \%$ of the students turn to them in stressful situations. $2 / 3$ of nursing students turn for help or advice to relatives and friends. $1 / 3$ of the students asks for help from health care institution administration. Seeking help from college administration staff, lecturers or psychologist are rarely reported techniques by the students. Also students do not prefer to share the problems on social networks.

Almost every fifth student chooses harmful habits (alcohol, cigarettes) as a stress reliever. $13,1 \%$ of them use medications to reduce stress.

No statistically significant differences were found indicating that the year of study is related with the methods of coping the stress during internship (Anova test, $\mathrm{p} \geq 0.05$ ).

The positive experience expressed by the surveyed nursing students can be considered as a mean to successfully adapt psychologically and to help reduce stress during internships (Table 1). The results presented in the table suggest optimistic point of view

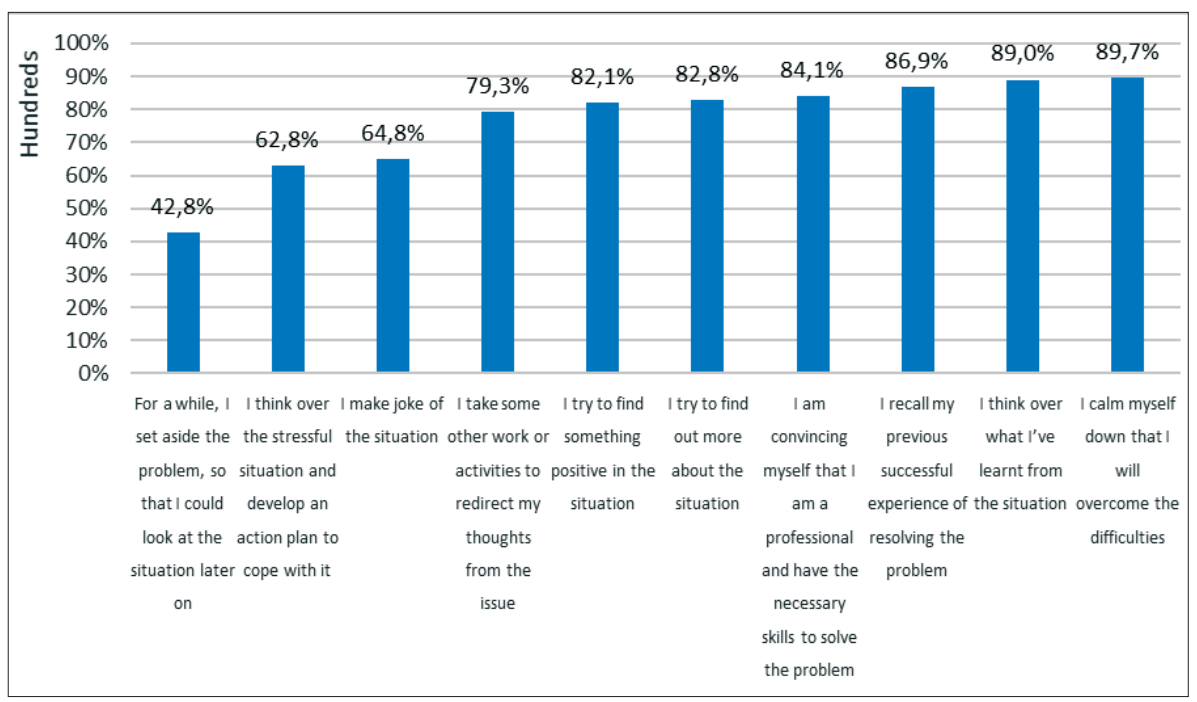

Fig. 8. Rational stress coping methods used by the students $(\mathrm{N}=145)$

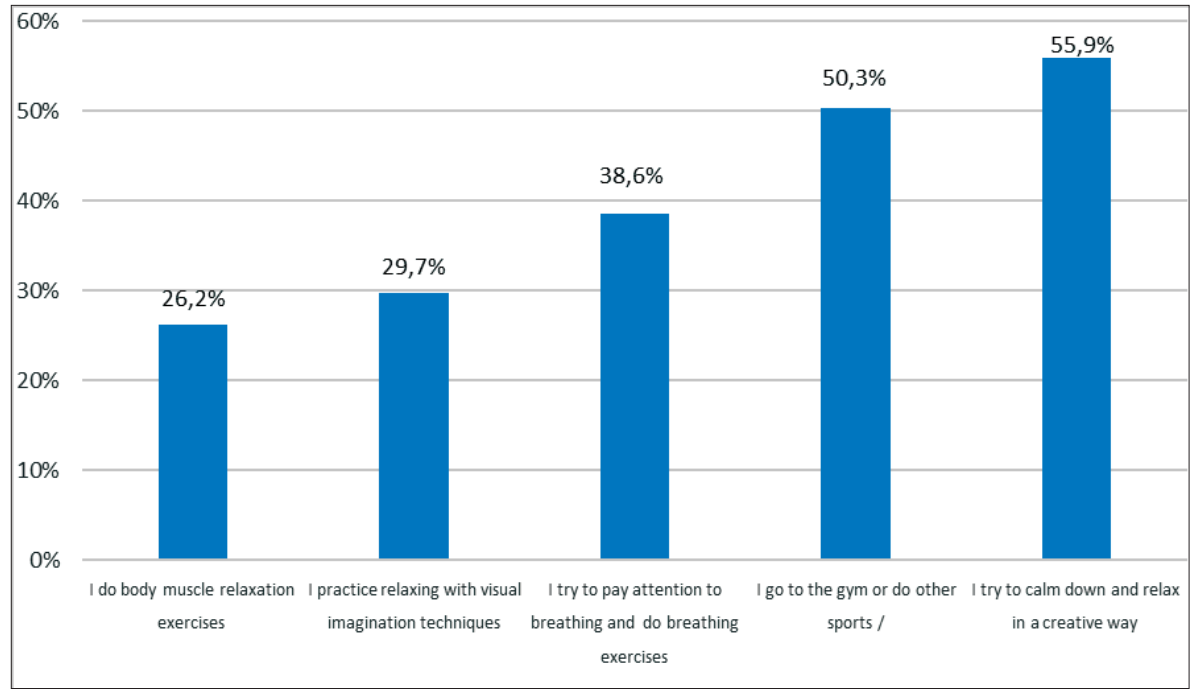

Fig. 9. Relaxation stress coping methods used by the students $(\mathrm{N}=145)$ 
and show that each nursing student in the study had something positive to say about their professional practices. The 7 categories highlighted in the table provide insight into key areas that reflect nursing students' perceptions of what they want to see and feel during the internship.

For nursing students it is very important praise and encouragement demonstrated by nursing practitioners and nursing managers. Students find it important to notice their well-done actions, " $<$... positive evaluations of nurses during manipulations ... $>$. They feel psychological security and are delighted by commendation $<\ldots$ that you are really in your place and going in the right direction... $>$ ", " <... how I performed the procedure by

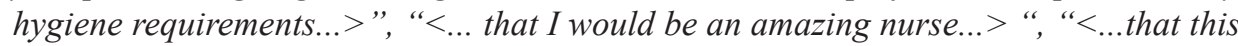
profession is very suitable for me. Such words are really motivating... >”.

Friendly team and close cooperation are also important factors allowing one to feel good psychologically during professional internships (Table 1). The exemplary communication described by nursing students is based on the principles of teamwork, cooperation, respect, a warm attitude toward a student as a future colleague. The phrases of authentic statements by nursing students give a clear idea of what a friendly team and close cooperation is: "<... I was welcomed so warmly that I had to say goodbye with tears in my eyes...>", " $<\ldots$ friendly staff who help to understand the nursing profession... $>",<\ldots$ involves you in clinical situations and analyse them together... ”.

Receiving information and consultations from nurses - mentors is another prerequisite for feeling good psychologically during professional internships. The roles of the nurse as an advisor, assistant or teacher are revealed in the following statements of nur-

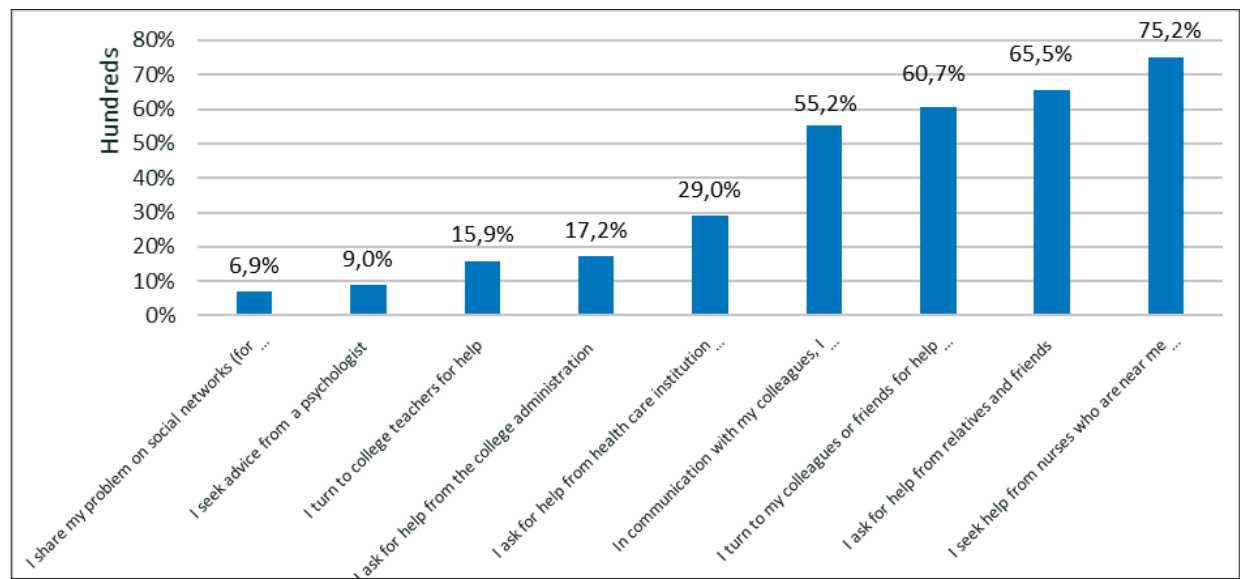

Fig. 10. Organizational and social stress coping methods used by the students $(\mathrm{N}=145)$

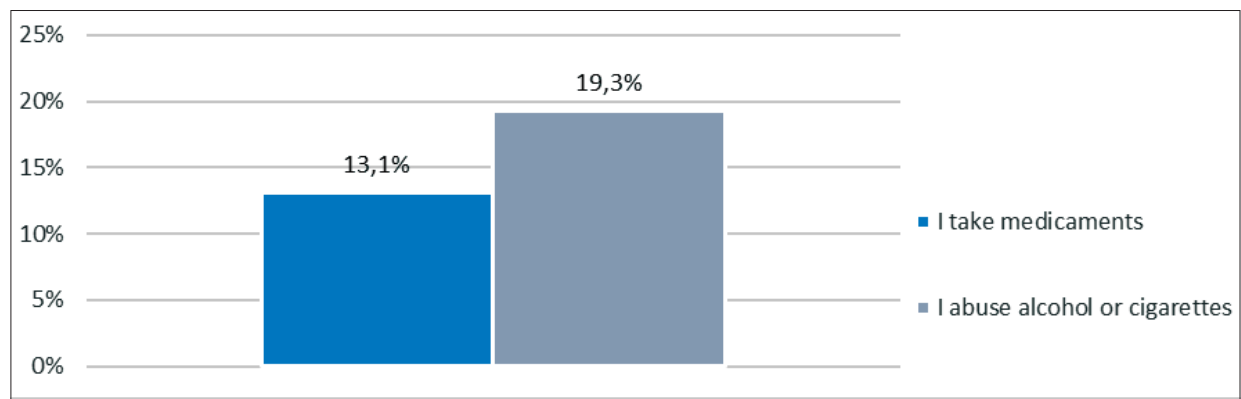

Fig. 11. Pharmaceutical and health damaging stress coping methods used by the student $(\mathrm{N}=145)$ sing students: $<\ldots$ warm and cordial explanations and teaching...>", "<... human advice on how to make the nursing procedure easier...>”, “< $<$.. makes remarks personally without hearing the patients around...>".

Nursing practice is a place where students want to feel confidence and have the opportunity to act independently: "<... I had an unreal mentor who trusted me $100 \%$...>", "< ... a mentor always allows the work to be done independently... ", " $<\ldots$ I had a chance to meet such doctors who always refer to you as already a nurse...>", "<... all the nurses were very supportive of our work and efforts...>".

A patient-friendly attitude towards the student is very important for students. It can be assumed that the student is in a new learning environment, experiencing many new learning situations, performing some nursing manipulations for the first time. Situations that students identify as supporting, inspiring and at the same time reducing stress are when: $"<\ldots$ patients willingly and kindly accept me as a student, trust my knowledge and practical skills...>", "I had to inject the patient's vein and the patient himself, seeing that I was a student, encouraged me to try", “< ... they're glad we're learning... >".

Nursing students feel the support and help of nursing mentors. The students mentioned that the nurses-mentors carry out teaching and consul- 
Table 1. Nursing students positive experience during their professional internship

\begin{tabular}{|c|c|c|}
\hline Cat & $\mathbf{N}$ & Authentic examples \\
\hline $\begin{array}{l}\text { Student } \\
\text { praise and } \\
\text { encourage- }\end{array}$ & 36 & $\begin{array}{l}\text { „Compliments from the head nurse that the work done during the internship shows that you are really in your place } \\
\text { and going in the right direction". } \\
\text { "At the end of the internship, the mentor encouraged me by saying that I would be an amazing nurse". } \\
\text { "A strong compliment from the head nurse how I performed the procedure by hygiene requirements". } \\
\text { "Positive evaluations of nurses during manipulations". } \\
\text { "During some internships, the nurses were very happy with my work and did not even hide it, they even told the } \\
\text { doctors what a great student I am, and they say that this profession is very suitable for me. Such words are really } \\
\text { motivating". }\end{array}$ \\
\hline y- & 32 & 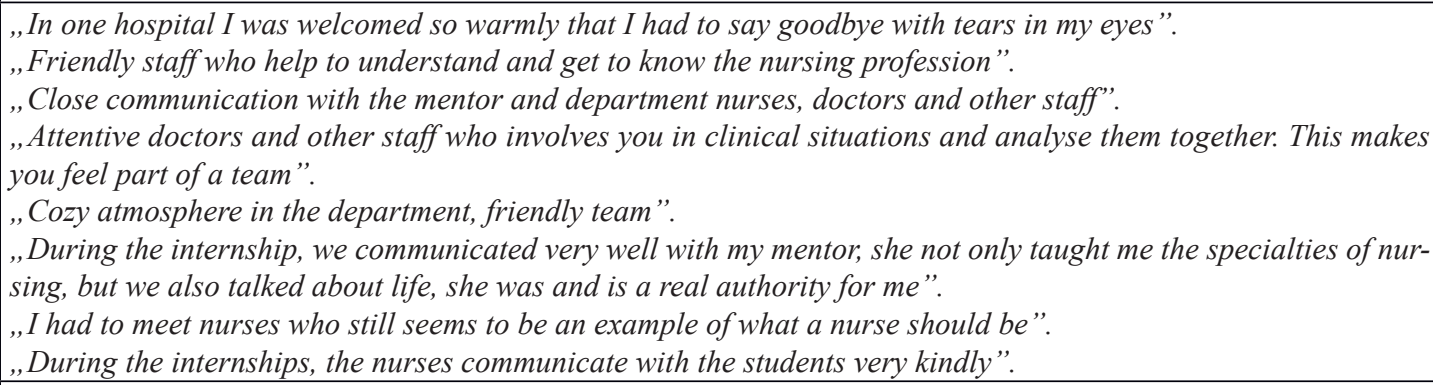 \\
\hline & 31 & $\begin{array}{l}\text { "During all the internships, my positive emotions were caused by the nurses "willingness to teach me”. } \\
\text { „Explanation of diseases, interventions and training”. } \\
\text {,"Warm and cordial explanations and teaching". } \\
\text { „When nurses realize you 're a student and don 't know as much as they do, they create an atmosphere where you 're } \\
\text { not afraid to ask”. } \\
\text { „Human advice on how to make the nursing procedure easier: easier to inject, take blood”. } \\
\text { „My mentor knew how to connect properly with students, so she reassured me, introduced me to the pending jobs } \\
\text { and challenges, always explained before assigning jobs, never left me alone”. } \\
\text { „Explains the mistakes made and makes remarks personally without hearing the patients around”. }\end{array}$ \\
\hline $\begin{array}{l}\text { ence } \\
\text { ent } \\
\text { e } \\
\text { u- } \\
\text { act } \\
\text { n- }\end{array}$ & 2 & $\begin{array}{l}\text { "During one internship I had an unreal mentor who trusted me 100\%, was equal to me, never criticized me while } \\
\text { patients had heard }<\ldots . .>\text { I have got an answer to every question, I went to the internship every day with a smile } \\
\text { and without any stress". } \\
\text { „Nurses take students together to do various manipulations together, allow to perform them independently". } \\
\text { "A mentor always allows the work to be done independently. This builds self-confidence". } \\
\text { "Of course, it took us a while to gain confidence, but all the nurses were very supportive of our work and efforts", } \\
\text { "In one department I had a chance to meet such doctors who always refer to you as an already real nurse }<\ldots> \\
\text { personally, for me here is the greatest recognition". }\end{array}$ \\
\hline $\begin{array}{l}\text { Pa } \\
\text { gr } \\
\text { ar } \\
\text { ve }\end{array}$ & 23 & $\begin{array}{l}\text { „Patient smiles and gratitude to me". } \\
\text { „Patients willingly and kindly accept me as a student, trust my knowledge and practical skills, and if any manipu- } \\
\text { lation fails, they don 't get angry and encourage me to try again". } \\
\text { „Patients 'nice feedback about me and their desire the manipulations to be done by me”. } \\
\text { „I had to inject the patient's vein and the patient himself, seeing that I was a student, encouraged me to try”. } \\
\text {,The patient's relatives praised and thanked me for the good care and said many nice words". } \\
\text { „Most patients are willing to let students do the procedures for them, they 're glad we re learning”. }\end{array}$ \\
\hline $\begin{array}{l}\text { H } \\
\text { su } \\
\text { fr } \\
\text { se }\end{array}$ & 18 & $\begin{array}{l}\text { „Constant support of the department staff in the stressful situation”. } \\
\text { „Sincere desire of the nurse to provide help and emotional support". } \\
\text { „Encouraging nurses not to be upset if something goes wrong”. } \\
\text { „Help, understanding, attention of the nurses”. }\end{array}$ \\
\hline $\begin{array}{l}\text { Useful and } \\
\text { meaningful } \\
\text { clinical }\end{array}$ & 11 & $\begin{array}{l}\text { "I had to care a young man after a stroke. I contributed to his nursing every day and it was extremely good to see } \\
\text { him recovering step by step". } \\
\text { "A very good feeling when a long-term patient wakes up from a coma, or his condition improves from completely } \\
\text { bad to better, can raise his hand, smile”. }\end{array}$ \\
\hline
\end{tabular}


ting activities. However, students singled out the support and help shown to them. It can be assumed that not only the professional experience of senior colleagues, but also the observation when it is psychologically difficult for students - allows to avoid negative emotional experiences during professional internships. This is illustrated by the following statements: "Constant support of the department staff in the stressful situation", "Sincere desire of the nurse to provide help and emotional support".

For students, practice is a place where they achieve learning outcomes. When evaluating internships, students mark out clinical situations in which they had a high opportunity to see severely ill but recovering patients: " $<$ I had to care a young man after a stroke. I contributed to his nursing every day and it was extremely good to see him recovering step by step $>$ ", " $<A$ very good feeling when a long-term patient wakes up from a coma $>$ ".

\section{Conclusions}

1. Stress is a common phenomenon among nursing students. Students experience stress in a variety of situations. Factors related to work organization and conditions are the main causes of stress. Lack of staff, heavy workloads, unexpected situations and unplanned jobs are the most common stressors for nursing students.

2. External factors, although not directly related to professional practice, may be of concern to students: reforms related to nursing and health care, negative information on medical staff in media, not very positive attitude towards nurses in society.

3. Communication and collaboration are very important in the professional practice of nursing students. Nursing students are most sensitive to the disrespectful behaviour of patients, gossip directed against them, and public criticism from staff.

4. Most nursing students feel stress related to the fear of infection of various infectious diseases. This study was conducted before the onset of coronavirus infection (COVID-19) in Lithuania and worldwide. Therefore, it can be assumed that the iterance of the study during the pandemic period would further increase the fears associated with the fear of infectious diseases (especially COVID-19).

5. Rational methods are the most popular among nursing students in dealing with stressful situations during professional internship. Most of them calm themselves down that they will overcome the difficulties, think over what has been learned from the certain situation, recall previous successful experience of resolving the problem, convince themselves of being professionals and having necessary skills to solve the problems.

6. Relaxation techniques are less commonly used among nursing students. Only every second nursing student of the study tries to reduce stress during internships by calming down and relaxing in a creative way or going to the gym or doing other sport.

7. Organizational and social methods are not very popular among nursing students. Nursing students have the most confidence in nursing practitioners who are close to their place of practice. In stressful situations, relatives and friends are also important for the nursing students when seeking help and advice.

8. The positive experience expressed by nursing students can be considered as measures aimed at helping to successfully adapt psychologically and reduce stress during professional internship. These measures include: students ${ }^{6}$ praise and encouragement, friendly team and close cooperation, a nurse-mentor as a teacher and consultant, confidence in student and the opportunity to act independently, patient's gratitude and benevolence, help and support from nursementor, useful and meaningful clinical situations.

\section{References}

1. Aslan H, Pekince H. Nursing students' views on the COVID-19 pandemic and their percieved stress levels [published online ahead of print, 2020 Aug 17]. Perspect Psychiatr Care 2020;10.1111/ppc. 12597.

https://doi.org/10.1111/ppc.12597

2. Beh LS. Job stress and coping mechanisms among nursing staff in public health services. International Journal of Academic Research in Business and Social Sciences 2012; 2(7):131-176.

3. Bektaş H, Terkes N, Özer Z. Stress and ways of coping among first year nursing students: a Turkish perspective. International Journal of Human Sciences 2018;15(1):319-330. https://doi.org/10.14687/jhs.v15i1.4626

4. Bhurtun HD, Azimirad M. Saaranen T, Turunen H. Stress and coping among nursing students during clinical training: an integrative review. Journal of Nursing Education 2019;58(5):266-272. https://doi.org/10.3928/01484834-20190422-04

5. Decamps G, Boujut E, Brisset C. French college studnets' sports internship and its relations with stress, coping strategies and academic success. Fronties in Psychology 2012; 3:104-111. https://doi.org/10.3389/fpsyg.2012.00104

6. Gamal EA, Khulood AA. Stress and coping strategies among Saudi nursing students during clinical education. Perspectives in Psychiatric Care 2018;54(2):198-205. https://doi.org/10.1111/ppc.12223

7. Kim Y, Park H, Hong SS, Chung HJ. Effects of a neonatal nursing internship program on students' stress, self - efficacy, and confidence. Child Health Nurs Research 2018;24(3):319-328. https://doi.org/10.4094/chnr.2018.24.3.319

8. Labrague LI, McEnroe-Petitte DM, Papathanasiou IV, Edet OB, Tsaras K, Leocadio M.C. Stress and coping strategies among 
nursing students: an international study. Journal of Mental Health 2018;27(5):402-408.

https://doi.org/10.1080/09638237.2017.1417552

9. Lovrić R, Farčić N, Mikšić Š, Včev A. Studying during the COVID-19 pandemic: a qualitative inductive content analysis of nursing students' perceptions and experiences. Education Sciences 2020;10(7):188.

https://doi.org/10.3390/educsci10070188

10. Ören B, Zengin N. Assessing health threatening problems among nursing or Midwifery students during the clinical education course in Turkey. Iran J Public Health 2019;48(1):85-94. https://doi.org/10.18502/ijph.v48i1.786

11. Pareira FGF, Caldini LN. Assesment of stress in the inclusion of nursing students in hospital internship. Invest Educ Enferm 2014;32(3):430-437. https://doi.org/10.17533/udea.iee.v32n3a08

12. Rabei S, Mourad G, Hamed AED. Work stress and sleep disturbances among internship nursing students. Middle East Curr Psychiatry 2020;27 https://doi.org/10.1186/s43045-020-00032-1

13. Waled AMA, Badria MA. Nursing students' stress and coping strategies during clinical training in KSA. Journal of Taibah Iniversity Medical Sciences 2019;14(2):116-122.

https://doi.org/10.1016/j.jtumed.2019.02.002

\section{BENDROSIOS PRAKTIKOS SLAUGOS STUDENTŲ PATIRIAMAS STRESAS PROFESINIŲ PRAKTIKŲ METU: PRIEŽASTYS IR VALDYMO METODAI \\ V. Piščalkienė, L. Navickienė}

Raktažodžiai: slaugos studentai, stresas, profesinès veiklos praktikos, streso priežastys, streso valdymo metodai.

Santrauka

Profesinis stresas - reiškinys, su kuriuo susiduria tiek sveikatos priežiūros įstaigose dirbantys medikai, tiek medicinos, slaugos mokslų studentai. Ankstyvas streso požymių identifikavimas, laiku taikomi tiksliniai metodai - priemonès, leidžiančios išlaikyti saugią socioedukacinę aplinką realioje praktikos vietoje.

Tyrimo tikslas - atskleisti slaugos studentų profesinių praktikų metu patiriamo streso priežastis ir jo valdymo metodus.-

Tyrimo medžiaga ir metodai. Tyrimui pasirinkta kiekybinè tyrimo strategija. Tyrimo priemonę sudaro du pagrindiniai klausimų blokai, iš kurių vienas skirtas streso priežasčių, kitas - streso valdymo metodų atskleidimui. Streso priežastims nustatyti pateikti 27 teiginiai, iliustruojantys keturias stresorių sritis: 1) darbo turinys ir klinikinès situacijos; 2) darbo sąlygos ir organizavimas; 3) bendravimas ir bendradarbiavimas; 4) išorès veiksniai.

Priemonių, kurias studentai naudoja streso valdymui, atskleidimui, ị klausimyną įtraukti 26 streso ịveikos metodai, priskiriami keturiems streso valdymo metodų tipams: 1) relaksaciniai metodai; 2) racionalūs metodai; 3 ) organizaciniai ir socialiniai metodai; 4) medikamentų vartojimas ir žalingi ịpročiai. Pateiktas vienas atviro tipo klausimas, kurio tikslas - atskleisti teigiamas studentų patirtis praktikos metu. Tyrime dalyvavo 145 bendrosios praktikos slaugos studijų programos studentai.

Rezultatai. Stresas tarp slaugos studentų yra gan dažnas reiškinys. Mažesnị ar didesnị stresą patiria visi slaugos studentai. Dažniausiai stresą kelia veiksniai, susiję su darbo organizavimu ir sąlygomis. Racionalūs streso valdymo metodai, populiariausi tarp slaugos studentų, yra stresinių situacijų sprendimas profesinių praktikų metu. Slaugos studentų išsakytą pozityvią patirtị praktikų metu galima traktuoti kaip priemonę, leidžiančią sẻkmingai adaptuotis psichologiniu požiūriu bei padedančią mažinti stresą profesinių praktikų metu. Remiantis tyrimo duomenimis, galima išskirti tokias studentus palaikančias priemones, kaip pagyrimas ir paskatinimas, draugiškas kolektyvas ir glaudus bendradarbiavimas, slaugytojas-mentorius (čia: mokytojas ir konsultantas), pasitikejjimas studentu ir galimybè veikti savarankiškai, pacientų padèka ir geranoriškumas.

Adresas susirašinėti: viktorija.piscalkiene@go.kauko.lt

Gauta 2020-11-10 